\title{
Cognitive and perceptual influences of architectural and urban environments with an emphasis on the experimental procedures and techniques
}

\author{
Parastou Naghibi Rad ${ }^{1}$, Farzaneh Behzadi $^{2}$, Abbas Yazdanfar $^{2}$, Hessam Ghamari $^{3}$, Erfan Zabeh $^{4,+}$, Reza Lashgari $^{1, *}$ \\ 1 Institute of Medical Science and Technology, Shahid Beheshti University (SBU), Tehran, Iran \\ 2 School of Architecture and Environmental Design, Iran University of Science and Technology (IUST), Tehran, Iran \\ 3 Department of Family and Consumer Science, California State University, Northridge, California \\ 4 Electrical Engineering Department, Sharif University of Technology, Tehran, Iran \\ + Current address: Department of Biomedical Engineering, Columbia University, New York, NY, USA \\ * Correspondence: rezalashgari@ipm.ir
}

Keywords: Environmental Psychology, Applied psychology, Neuroarchitecture, Architecture, Neuroscience

\begin{abstract}
With the expansion of urban life and technological development, the human interaction with civil environments became inescapable. Yet, less is known about the psychological and cognitive consequences of human contact with buildings, constructions, and urban environments. In this study, we propose a systematic review of the recent attempts and experimental studies elaborating upon the emotional and perceptual influences of architectural environments on the human brain with an emphasis on the experimental procedures and techniques. To do so, the primary experimental studies were selected among the recent peer-reviewed literature, based on the PRISMA systematic review protocol. The pruned experimental articles contain a wide range of techniques and recording instruments for quantification of behavior and brain activities including Electroencephalography (EEG), eye tracking, functional Magnetic Resonance Imaging (fMRI) techniques, and psychological measurements. We categorized the task-space of selected articles based on the environment and its stimuli properties into six subfields of "interior design", "urban design", "formal and spatial organization", "facade design", "energy and building", and "natural scene". Following this context-based categorization, the distribution of employed recording techniques was distinguished for each task-space division. Accordingly, more than 50 percent of the experimental studies were incorporated into the first two divisions. Surprisingly, our survey indicates there is a lack of multidisciplinary studies for the "Formal and Spatial Organization" category despite the obvious effects of the environment's spatial organization on the occupant's behavior, emotions, and performance. Among the existing literature, the EEG recording was the most frequently employed neuroimaging technique due to the technical efficacy of its recording setup and the high temporal resolution of its electrophysiological signals. In contrast, the fMRI studies were scarce probably because of restrictions in the implementation of some of the space-tasks. Although
\end{abstract}

fMRI techniques have low temporal resolutions, this limitation does not make an issue in architectural tasks, where the temporal dynamics of the task have a slow pace. Moreover, the implication of fMRI imaging can provide higher spatial resolutions comparing to EEG techniques. Higher spatial resolutions are essential for advanced studies in the field of neurobehavioral architecture as it can lead us toward precise localization of brain circuits involved in complex neuro-architecture tasks. The extracted distribution of neuroimaging techniques suggests consideration of fMRI and eye-tracking techniques for future studies. In this review with extracting distribution of current literature and employed techniques, we provided an experimental framework for in the field of neuroarchitecture and we aimed to shed lights on vacancies and gaps that need to be filled in future studies.

\section{Introduction}

Cities and buildings are places where people spend most of their time to live, satisfy their needs and requirements, and especially shape their lives [1]. A variety of influential stimuli impact people's life, psycho-emotional qualities, overall health, and wellbeing in any given environment $[2,3,4,5]$.

Environmental psychologists have been studying the influences of spaces on human behavior through empirical studies since the early 20th century. They observed how individuals differently behave in distinctive environments [1] and how specific physical elements and their arrangements capture attention, evoke feelings, and create a lasting impression. They studied how various architectural design features impact human experience types such as work motivation, stress, anxiety, pleasure, and restrictiveness in built environments

Several studies indicated that architects could directly investigate the users' opinions and feelings of spaces. However, since the ability to process information without consciousness is less than $1 \%$ of the ability of unconscious processing [6], it has been stated that most stimuli can affect individuals on a subconscious level. That is, although people may be influenced by stimuli, they are not necessarily aware of the effect[1]. 
Using neuroscientific tools, neuro-architecture studies focus on the effects of built environments on their inhabitants $[7,8]$, and current studies are fostering a novel understanding of the neuroscience behind the way people perceive and experience the built environment $[9,10,11]$. How the human brain and mind experience architectural settings is a promising research domain in the neuroscience of architecture [12]. With these perspectives, researchers can uncover the causes of changes in human mood and behavior; they can measure changes in brain functions that happen as a result of the interaction between the brain and built environments[1]. The rapid growth of functional brain imaging methods allowed cognitive neuroscience to link architecture [13], creating the field of neuro-architecture. Additionally, brain imaging and behavioral studies have been regularly used to distinguish the state of human brain function or non-human subjects with visual stimuli in either conscious or unconscious conditions [14, 15, 16]. Based on this perspective, design features reflect the principles associated with evolutionary psychology that influences and produces predictable brain wave responses [17]. Therefore, a more detailed understanding of how brain perceives and processes the features of building components is a promising academic goal in the field of neuro-architecture [18].

In this study, the impacts of different physical environments and their features on the brain were investigated, using assorted methods to study the interaction between environments and human brain activities. The integration of architecture and neuroscience disciplines can explain what might be 'better' or 'worse' in terms of design for humans due to key lessons in biology, cognitive science, and psychology [17].

\subsection{Background}

Combining architectural aspects and real-time measurements of brain activities, neuro-architecture has significantly advanced human understanding of the neural mechanisms underlying the wide-range effects of architectural features on the human brain. The main instruments used in this interdisciplinary field are neuroimaging, psychological measurement, and eye tracker. Despite the complexity of the brain function, advances in brain imaging techniques can boost studies focusing on the structure and function of the human brain [19]. Advanced noninvasive neuroimaging techniques allow researchers to directly observe brain activities while subjects perform various perceptual, motor, and/or cognitive tasks. By combining brain imaging with sophisticated experimental designs and data analysis methods, functions of brain regions and their interactions can be examined [20]. Table 1 briefly provides an overview of data measurement tools and illustrates their applications in experimental studies.

\section{Methods}

This study addresses two main questions:

- What methods have been applied by scholars to collect and analyze human responses and their feelings to different spaces?
- Which architectural areas have been studied more than others in neuro-architecture?

This systematic review was guided by the Preferred Reporting Items for Systematic Reviews and Meta-Analyses (PRISMA) approach [21] to perform the steps required in this study. It focused on the existing literature related to various fields of neuro-architecture that were studied in exterior, with immersing virtual reality or displaying on a monitor, walking through urban environments, measuring different brain imaging techniques, psychological measurements, and eye tracker.

\subsection{Inclusion criteria}

Systematic reviews have become progressively important in neuro-architecture. Accordingly, a collection of precise instructions was employed to design the research design, implement it, and report the results. The methodology applied to provide this systematic review was based on Cochrane Handbook [22].

\subsection{Search strategy}

The five databases (Science Direct, Web of Science, PubMed, Scopus, and Springer) provided a wide range of literature including studies concentrating on architecture, urban environments, and the neuroscientific contents. Preliminary research terms reflected several key concepts defined by this systematic review [23]. The main keywords of this paper were selected among neuro-architecture studies and experts' opinions. This study eventually settled on five fundamental keywords: built environment, architecture, neuroscience, electroencephalogram (EEG), and functional magnetic resonance imaging (fMRI) (Table 2).

A similar research strategy was applied to published literature in the databases. These keywords were searched to find related papers between September 2012 and September 2019. We chose 2012 since the first biennial Academy of Neuroscience for Architecture (ANFA) conference was held at that time. It was the first formal scientific conference in the field of neuro-architecture held in Salk Institute, California, the United States.

\subsection{Eligibility criteria}

The searched studies were characterized by these two items:

- They must be in the field of neuro-architecture and investigate the effects of the environment with some kinds of architectural features on human well-being and emotions.

- The research approach of the acquired studies must incorporate neuroscience and architecture or urban design including psychophysiological measurements, digital tools, and brain imaging techniques. 


\subsubsection{Screening and study selection}

The selected papers were screened in four steps: 1) Title screening of all the identified papers 2) Abstract screening of the excluded studies based on titles 3) Full-text screening 4) Ensuring that the selected paper contents outline in research questions. The obtained papers consisted of both experimental and review studies, but we only concentrated on experimental ones since the goal was to investigate research questions about the methods, measurement tools, and study context. Since reviews included and summarized findings from other studies, they had to be excluded from the main selected studies while extracting six main categories.

\subsection{Quality appraisal}

The quantitative version of the McMasters rating tool (McMasters Critical Review form)[24] was used to score and review all levels of the identified studies. The form is frequently used within systematic reviews that synthesize quantitative studies $[24,25,26,27,28]$ and includes some criteria and domains to assess the quality of selected papers. All studies were assessed by first and second authors' Yes/No answers and investigated whether each of them was qualified or not. Table 3 shows these criteria and domains in detail.

\section{Result}

Thirty-three studies were included in this systematic review. The selection process is demonstrated in Fig. 1, containing twenty-five experimental studies and eight reviews. Only experimental studies were finally used because the goal was to search for previously used methods and instruments.

\subsection{Characteristics of studies}

EEG was used in seventeen studies, eight of them employed emotive EEG as an instrument for measuring brain activity, and six studies employed fMRI as the research instrument. The remaining ten studies used other instruments such as questionnaires, eye tracker, and physiological responses for data measurements. Fig. 2 demonstrates all instruments employed to record brain activity, and how many times each of them was used in finally selected studies. Since several studies were literature review, only experimental studies were considered as the main source of this systematic review due to the identification and surveying of data measurement tools. Table 4 shows the characteristics of all studies employed in this research. The results show that neuroimaging was the most efficient method, and eye tracker was the least employed instrument applied to record brain activities.

\subsection{Quality assessment}

Inter-rater reliability between the two authors was between moderate and substantial (Cohen Kappa (unweighted) = 0.66). Table 3 shows the methodological quality assessment of each study. The range of quality appraisal scores for the included papers were $7-13$, and the average was 11.46 .

\subsection{Summary of findings}

Twenty-five experimental studies were identified using neuroscience approaches in their methodologies. They were operated in both laboratories and urban environments using images, displaying movies, walking through, or virtual reality immersions. The six main extracted categories from final sources were shown in Fig. 3.

\subsubsection{Interior design}

Several studies showed the impacts of different interior forms on human brain activities and demonstrated the connection between human feelings toward the spaces characterized by different geometries. Banaei et al. (2017)[29] extracted different clusters of form features to find out their impression using a mobile EEG setup synchronized to head-mounted VR. The results showed that curvature geometries made higher pleasure and arousal ratings, and increased theta activity in the anterior cingulate cortex (ACC), whereas rooms with more linear geometries caused lower pleasure and arousal ratings. Shemesh et al. (2015) [30] investigated differences between expert and non-expert views in the perception of spatial spaces using three neuroscientific devices including wireless EEG, wireless Eye tracker, and emotional engagement measurement (EEM) systems. The results showed that the non-expert group was more interested in curvy spaces and felt more pleasant feeling in familiar ones than the expert one. Pati et al. (2016)[13] identified the effects of the curve and sharp contours in interior health care settings on patterns of amygdala activation and behavioral response using fMRI. The results showed higher amygdala activation in stimuli including landscape and healthcare objects associated with sharp contours.

Vartanain et al. (2015)[31] used fMRI to investigate the effects of ceiling height that were either opened or enclosed on human perception and their neural activities. They argued that the beauty judgment for high/low ceiling contrast showed activation in the left presumes and left middle frontal gyrus. During judgment in open-enclosed contrast, the left middle temporal gyrus and right superior temporal gyrus were activated. Enhancing sleep quality to compare the east-west (E-W) bed direction versus the north-south $(\mathrm{N}-\mathrm{S})$ direction to propose the best bedroom design, Hekmatmanesh et al. (2019)[32] investigated the effects of bed orientation on human wellbeing while the sleep EEG signals were being recorded. The results demonstrated that the average energy of the frequency band in the N$\mathrm{S}$ direction increased more than the $\mathrm{E}-\mathrm{W}$ one, and sleep in the $\mathrm{N}-\mathrm{S}$ direction was more beneficial than the E-W one. Zou et al. (2019)[33] classified EEG data and investigated four architectural design features (color, texture, space layout, and sequenced spaces) affecting occupant's work motivation using virtual reality. Artificial Neural Network (ANN) showed the best performing model in user-dependent/independent analysis. Also, its accuracy of user-independent analysis was lower 
than the user-dependent one. Ergan et al. (2018) [34] investigated the impacts of architectural design features on stress and anxiety. They used an integrated virtual reality and body sensor network (BSN) platform evaluated by EEG, galvanic skin response (GSR), facial or vision-based electromyography (EMG), and photoplethysmogram (PPG). The level of luminance, of natural daylight, of the color of surfaces, of openness of spaces, and of the presence or absence of visual cues were considered architectural design features to reflect the two ends on a semantic scale of relaxing for stressful feelings. Moreover, $40 \%$ of EEG oscillations were higher across all channels on all band frequencies in the stress-reducing compared to the stress-inducing environments. $141 \%$ had an increase in galvanic skin response (GSR), and lower heart rate variability in photoplethysmogram (PPG) in the stress-reducing environment compared to the stress-inducing environment. Vecchiato et al. (2015)[35] used EEG to investigate how people experienced architectural environments. The results showed that pleasant, novel, and comfortable interiors produced a de-synchronization of mu rhythm over the left sensorimotor regions. More pleasant and less familiar interiors activated the left frontal areas (theta and alpha bands). Also, theta band enhancement was observed across the frontal lobe by increasing the level of comfort. Higuera-Trujillo et al. (2019)[36] assessed how the combinations of different environmental satisfaction sources (CESS) of waiting rooms influenced stress reduction in health centers. Subjective evaluations and stress levels were measured by both neurophysiological responses included electrodermal activity (EDA), heart-rate variability (HRV), EEG signals, and psychological responses showing stress self-assessment and the State Anxiety Inventory. They suggested that a combination of environmental satisfaction sources had an important synergistic effect on psychological and neurophysiological levels and underlined the importance of auditory and olfactory stimuli.

\subsubsection{Urban environments design}

Two studies in this category explored the relationship between emotional experiences and the variation of urban environments $[37,38]$. They compared green environments with nonnatural environments using a portable EEG device. Aspinall et al. (2013)[37] investigated participants walking through three types of urban environments (shopping street, green space, busy space). Neale et al. (2017)[38] assessed older people's neural activities in urban environments with different individuals. Higher levels of "engagement" [38] and "meditation" [37] were observed in green spaces compared to busy and quiet (non-natural) environments.

Two other studies explored the relationship between the variation of urban environments and brain wave oscillations using portable EEG. Karandinou and Turner (2018)[39] aimed to find brain responses like wayfinding and decision making in their journeys. They showed a short and intense peak of beta frequency. Also, encountering red lights at a pedestrian crossing showed a decrease in beta, while in familiar places beta was lower. Al-barrak et al. (2017)[40] investigated the impacts of urban environments and their restorative power on hu- man brain activities. The results demonstrated high meditation levels in gardens and cafes in comparison with supermarkets. Also, higher alpha activity was noticed in these places. In addition, a higher beta activity, related to mental activities, was observed in supermarkets.

Zhang et al. (2019)[41] compared the brain activity of natural landscapes and landscape gardens with color photographs using fMRI. The results showed strong activations in the inferior occipital lobe, left superior parietal lobule (SPL), right fusiform gyrus, right cuneus, and right hippocampus that may be specifically associated with the appreciation of gardens in comparison with natural landscapes. Using the MEG apparatus, Sakellaridi et al. (2015)[42] discussed how the human brain encoded spatial information required to make spatial decisions while exploring an urban environment. They found that neural processing was dependent on the types of street networks. The result showed a strong concentration on right frontal and prefrontal areas during processing street length and regularity index. Patches in prefrontal areas were also involved in processing the number of street intersections. Using EEG, Olszewska-Guizzo et al. (2015)[43] investigated how window views taken from different floors of a high-rise block with varying extents of green cover can impact the brainwaves of viewers. Their findings revealed the association between brainwave patterns and positive emotional states, motivation, and visual attention that may increase by the extent of green cover within window views from different floors of a high-rise block.

\subsubsection{Façade design}

Two studies explored the impacts of façade geometry on occupants' perception. One using EEG and the other physiological response. Naghibi Rad et al. (2019)[44] employed EEG to investigate the subjects' emotional response to geometrical window shapes of building facades marked as pleasant and unpleasant. The results showed increased activity for unpleasant windows including triangular and triangular arch shapes in both frontal and posterior-occipital channels in comparison with the pleasant ones including rectangular, square, circular, and semi-circular arch shapes. ERP amplitudes of the right hemisphere were significantly larger than the left one in response to both unpleasant and pleasant ones. Chamilothori et al. (2019)[45] assessed façade variations including three configurations of an equal aperture ratio: an irregular distribution of openings, regular distribution of openings, and venetian blinds by virtual reality immersion. They combined both subjective (self-reported evaluation) and objective (heart rate and skin conductance) in participants' responses. Their Findings revealed that irregular variation of the façade geometry was consistently evaluated among context scenarios as more pleasant, interesting, and exciting than the regular façade variation. Moreover, façade geometry and sunlight pattern significantly influenced participants' heart rate, but not their skin conductance response. 


\subsubsection{Formal and spatial organization}

Using fMRI, Bermudez et al. (2017)[46] presented an experimental study to provide preliminary evidence of differences in brain activity patterns and subjective states elicited by architectural design for assessing contemplative experience. The results showed significantly more activation in both the left postcentral gyrus and the left inferior parietal lobule in the contemplation including buildings (the experimental group) compared to ordinary buildings (the control group). Mahdizadeh Hakak et al. (2016)[47] investigated different perceptions of the abstract spatial environment and its influence on the role of pre-central gyrus focused on three different categories of designed environments (fully designed, semi-designed, and abstract designed). The EEG results showed a decrease in beta $2(18.5-21 \mathrm{~Hz})$ activity for the fully designed environment in comparison with the abstract ones, and beta $3(21.5-30 \mathrm{~Hz})$ activation showed a small difference between these two environments. A comparison between abstract designed and semidesigned environments indicated a big difference in both betaband frequencies in the precentral gyrus.

\subsubsection{Energy and building}

Using EEG, Son et al (2018)[48] explored the immediate impact of thermal pleasure to discover rapid psychological change from physiological data. A climate chamber consisting of two different rooms was used for this experiment. All conditions were the same except independent variables (temperature, radiant temperature, and relative humidity). In the following, thermal pleasure increased theta band frequency associated with pleasant emotion, but the beta related to pleasantness, satisfaction, or relaxation decreased in the indoor environment with the independent variables. Shan et al (2019)[49] investigated methods used in EEG to concentrate on improving humanbuilding interaction under different indoor air qualities. Machine learning-based EEG pattern recognition methods were also investigated as feedback mechanisms. The results revealed that the theta band correlated with subjective perceptions and the alpha band correlated with task performance. Tiago-Costa et al. (2016)[50] aimed to evaluate the influence of temperature and humidity directly on brain activity. A set of laboratory tests were undertaken in two different thermal environments $\neg$ $18^{\circ} \mathrm{C}-40 \% \mathrm{RH}$ (cold) and $35^{\circ} \mathrm{C}-80 \% \mathrm{RH}$ (hot) - to simulate sedentary work in these environments. The study was done using specific equipment including EEG, skin thermal sensors, and internal thermal sensors. The results from alpha activity analyses showed a decrease in the occipital lobe in hot thermal environments; it also decreased for half the time of the test and then rose in a cold thermal environment, leading to increased alpha activities in the occipital lobe. Beta waves in the cold environment were typically higher than the hot one.

\subsubsection{Natural scene}

Using fMRI, Pati et al. (2014)[51] explored the impact of viewing photographic sky compositions (representing nature stimuli) on brain activation patterns in healthy adults. The results revealed that the activation patterns produced by sky compositions and positive images were quite similar. The patterns of negative and neutral images were also similar. They explored brain regions associated with processing and visual hallucinations activated by traditional ceiling images, whereas sky compositions activated regions associated with dreaming. Tang et al. (2017)[52] demonstrated the effect of presenting different landscapes on brain region activity. They explored psychological and physiological responses and compared them to restorative values of four landscape types (urban, mountain, forest, and water). In addition, brain activity was detected during the presentation of different landscapes using fMRI. The results indicated increased activities in visual and attentional concentration brain areas when an urban environment was compared to a neutral stimulus. Moreover, water and mountains had the best attention-restorative abilities among the four landscape types, followed by forest and urban landscapes. This part of the systematic review summarizes various fields of neuro-architecture, measurement tools, and the number of cases through various kinds of methods previously used in the selected papers.

\section{Discussion}

This review investigated the relationship between architecture and human response to various environments, perception, and emotion in six separate categories. The findings generally confirmed that the most common and efficient technique in data recording is neuroimaging, especially fMRI and EEG. This study showed what methods and instruments are more efficient to do research for neuro-architects interested in identifying human emotion, feelings, and perception. It can provide a policy for the scholars in studying the effects of architectural features on brain development, associated cognitive functions, powerful and long-term impressions on human mood, behavior [24], and well-being to make progress and extend neuro-architecture among professionals. It also showed the importance of the lasting impacts of various architectural features on human perception. The results confirmed the research question about the methods employed to record data in each category. There were twenty-five studies categorized into six groups, and various methods and techniques of data recording were employed in each category. One of the most important aims was to recognize more the common and superior technique in each group. There were nine experimental studies researched in the interior design group, seven of them only used EEG or other techniques such as eye tracker, GSR, PPG, EEM, and EMG. Also, fMRI was employed in a couple of studies. The findings showed that $\% 77.8$ of experimental tasks of the interior design employed EEG, and only \%22.3 employed fMRI.

Furthermore, there were seven studies about urban environments, five of them used EEG in data acquisition: \%71.4 used EEG, one of them used FMRI, and another employed MEG. Due to the feasibility of walking through streets and among buildings, a portable EEG or emotive EEG, it has extensively been employed in urban environments, meaning that only $\% 14.2$ of this group used fMRI and similarly $\% 14.2$ used MEG. Half of each group in façade design and formal and spa- 
tial design alongside all three studies in energy and building design employed EEG for data measurements. fMRI was employed in both studies of natural scenes. The potential of employing a portable and emotive EEG in studies related to urban environments and walking through them illustrated the feasibility and importance of employing EEG among architects and urban planner experts in the field of neuro-architecture.

We could assert that EEG is the most common apparatus employed in these kinds of researches. It seems that this research field has extensive potential in various types of experimental tasks within different architectural features and review studies. Scholars can study human emotion, behavior, and brain activities using different approaches and considering such factors as age, gender, or expert and non-expert differences. An important implication of this study could be presenting an overall and valid framework to employ efficient methods and techniques used in recording brain data in various architectural environments with different features, especially applicable for researchers running experimental tasks in neuro-architecture. Scholars in this research area can face significant challenges such as the lack of reasonable laboratory settings, accessibility to professional instruments for running tasks and recording data, environmental interfering factors, and expensive instruments; however, they usually choose strict experimental controls in their laboratories to decrease the effects of contamination and co-intervention.

\section{Conclusion and Future work}

In conclusion, quantitate versus exploration of human experience assessed via various kinds of environments and techniques employed in each field of architectural space (e.g., interior, urban, built environment) was investigated to improve designing based on human preferences to achieve a policy for future designed spaces using neuroscientific insights instead of subjective feedback in architecture to propose a more appropriate and common design to employ in neuro-architecture. Generally, these kinds of studies explore human-building interactions and demonstrate a growing field placing human and his demands at the center of building design and operation[33] to achieve a better feature by lessening city and environmental stressors that may cause fatigue and many health problems in human daily life [40].

Moreover, in the field of cognitive neuroscience, there is an ongoing transition from simple lab oriented experiments toward experiments with more realistic and multi-dimensional environments, such as studying decision making under uncertain situations and navigation in complex environments $[53,54,55]$. With considering the fact that urban and architectural constructions are considered as complex environments, contemplation in the recent research lines of the cognitive neuroscience can provide additional insight on better understanding the influences of urban and civil environment on human beings.

Further research may also focus on providing an explanation and comparison of analysis methods of data processing and signal analysis for future extraction from various tech- niques such as fMRI, EEG, EMG, Eye tracker as well as immersion of virtual realities. Researchers can investigate and compare these methods to make comprehensive guidance and policy for neuro-architects.

\section{Acknowledgement}

The authors would like to thank Michael Francis Norwood of Griffith University for his invaluable guidance and comments.

\section{References}

[1] A. de Paiva and R. Jedon, "Short-and long-term effects of architecture on the brain: Toward theoretical formalization," Frontiers of Architectural Research, vol. 8, no. 4, pp. 564-571, 2019.

[2] S. C. Brown, C. A. Mason, T. Perrino, J. L. Lombard, F. Martinez, E. Plater-Zyberk, A. R. Spokane, and J. Szapocznik, "Built environment and physical functioning in hispanic elders: the role of "eyes on the street", Environmental Health Perspectives, vol. 116, no. 10, pp. 13001307, 2008.

[3] P. Dadvand, X. Bartoll, X. Basagaña, A. Dalmau-Bueno, D. Martinez, A. Ambros, M. Cirach, M. Triguero-Mas, M. Gascon, C. Borrell, et al., "Green spaces and general health: roles of mental health status, social support, and physical activity," Environment international, vol. 91, pp. 161-167, 2016.

[4] L. Trasande, C. Cronk, M. Durkin, M. Weiss, D. A. Schoeller, E. A. Gall, J. B. Hewitt, A. L. Carrel, P. J. Landrigan, and M. W. Gillman, "Environment and obesity in the national children's study," Environmental Health Perspectives, vol. 117, no. 2, pp. 159-166, 2009.

[5] M. Triguero-Mas, P. Dadvand, M. Cirach, D. Martínez, A. Medina, A. Mompart, X. Basagaña, R. Gražulevičienė, and M. J. Nieuwenhuijsen, "Natural outdoor environments and mental and physical health: relationships and mechanisms," Environment international, vol. 77, pp. 3541, 2015.

[6] D. Eagleman, Incognito (Enhanced Edition): The Secret Lives of the Brain. Knopf, 2011.

[7] E. A. Edelstein, "Building health," HERD: Health Environments Research \& Design Journal, vol. 1, no. 2, pp. 54-59, 2008.

[8] U. Nanda, D. Pati, H. Ghamari, and R. Bajema, "Lessons from neuroscience: form follows function, emotions follow form," Intelligent Buildings International, vol. 5, no. sup1, pp. 61-78, 2013.

[9] J. Zeisel, N. M. Silverstein, J. Hyde, S. Levkoff, M. P. Lawton, and W. Holmes, "Environmental correlates to behavioral health outcomes in alzheimer's special care units," The Gerontologist, vol. 43, no. 5, pp. 697-711, 2003. 
[10] J. P. Eberhard, Architecture and the brain: A new knowledge base from neuroscience. Greenway Communications/Östberg, 2007.

[11] S. Robinson and J. Pallasmaa, Mind in architecture: Neuroscience, embodiment, and the future of design. MIT Press, 2015.

[12] J. P. Eberhard, "Applying neuroscience to architecture," Neuron, vol. 62, no. 6, pp. 753-756, 2009.

[13] D. Pati, M. O'Boyle, J. Hou, U. Nanda, and H. Ghamari, "Can hospital form trigger fear response?," HERD: Health Environments Research \& Design Journal, vol. 9, no. 3, pp. 162-175, 2016.

[14] K. Devlin and J. L. Nasar, "The beauty and the beast: Some preliminary comparisons of 'popular'vs.'high' architecture and public vs. architect judgements of same.," Journal of Environmental Psychology, vol. 9, no. 4, pp. 333-44, 1989.

[15] K. Madani Nejad, Curvilinearity in architecture: Emotional effect of curvilinear forms in interior design. $\mathrm{PhD}$ thesis, Texas A\&M University, 2007.

[16] S. Kamkar, H. A. Moghaddam, and R. Lashgari, "Early visual processing of feature saliency tasks: a review of psychophysical experiments," Frontiers in systems neuroscience, vol. 12, p. 54, 2018.

[17] J. Hollander and V. Foster, "Brain responses to architecture and planning: a preliminary neuro-assessment of the pedestrian experience in boston, massachusetts," Architectural Science Review, vol. 59, no. 6, pp. 474-481, 2016.

[18] R. Chauhan and A. Moulik, "Translational science model for designing of outdoor environments for stress relief in an educational institute," Int. J. Innov. Res. Sci. Eng. Technology, vol. 3, pp. 17916-17936, 2014.

[19] W. Mier and D. Mier, "Advantages in functional imaging of the brain," Frontiers in human neuroscience, vol. 9, p. 249, 2015.

[20] X. Gui, C. Chuansheng, L. Zhong-Lin, and D. Qi, "Brain imaging techniques and their applications in decisionmaking research," Xin li xue bao. Acta psychologica Sinica, vol. 42, no. 1, p. 120, 2010.

[21] D. Moher, A. Liberati, J. Tetzlaff, D. G. Altman, D. Altman, G. Antes, D. Atkins, V. Barbour, N. Barrowman, J. A. Berlin, et al., "Preferred reporting items for systematic reviews and meta-analyses: The prisma statement (chinese edition)," Journal of Chinese Integrative Medicine, vol. 7, no. 9, pp. 889-896, 2009.

[22] J. P. Higgins, J. Thomas, J. Chandler, M. Cumpston, T. Li, M. J. Page, and V. A. Welch, Cochrane handbook for systematic reviews of interventions. John Wiley \& Sons, 2019.
[23] S. Liddicoat, "Spirituality in therapeutic spaces: Perceptions of spatiality, trace, and past rituals manifesting present occupation," Journal of Interior Design, vol. 44, no. 2, pp. 101-117, 2019.

[24] M. F. Norwood, A. Lakhani, A. Maujean, H. Zeeman, O. Creux, and E. Kendall, "Brain activity, underlying mood and the environment: A systematic review," Journal of Environmental Psychology, vol. 65, p. 101321, 2019.

[25] A. Lakhani, C. Townsend, and J. Bishara, "Traumatic brain injury amongst indigenous people: a systematic review," Brain injury, vol. 31, no. 13-14, pp. 1718-1730, 2017.

[26] A. Lakhani, M. Norwood, D. P. Watling, H. Zeeman, and E. Kendall, "Using the natural environment to address the psychosocial impact of neurological disability: A systematic review," Health \& place, vol. 55, pp. 188-201, 2019.

[27] R. Li, C. H. Sit, J. Y. Jane, J. Z. Duan, T. C. Fan, T. L. McKenzie, and S. H. Wong, "Correlates of physical activity in children and adolescents with physical disabilities: A systematic review," Preventive medicine, vol. 89, pp. 184-193, 2016.

[28] J. E. Swanberg, H. M. Nichols, J. M. Clouser, P. Check, L. Edwards, A. M. Bush, Y. Padilla, and G. Betz, "A systematic review of community health workers' role in occupational safety and health research," Journal of Immigrant and Minority Health, vol. 20, no. 6, pp. 1516-1531, 2018.

[29] M. Banaei, J. Hatami, A. Yazdanfar, and K. Gramann, "Walking through architectural spaces: the impact of interior forms on human brain dynamics," Frontiers in human neuroscience, vol. 11, p. 477, 2017.

[30] A. Shemesh, M. Bar, and Y. J. Grobman, "Space and human perception," 2015.

[31] O. Vartanian, G. Navarrete, A. Chatterjee, L. B. Fich, J. L. Gonzalez-Mora, H. Leder, C. Modroño, M. Nadal, N. Rostrup, and M. Skov, "Architectural design and the brain: effects of ceiling height and perceived enclosure on beauty judgments and approach-avoidance decisions," Journal of environmental psychology, vol. 41, pp. 10-18, 2015.

[32] A. Hekmatmanesh, M. Banaei, K. S. Haghighi, A. Najafi, et al., "Bedroom design orientation and sleep electroencephalography signals," Acta Medica International, vol. 6 , no. 1, p. 33, 2019.

[33] Z. Zou, X. Yu, and S. Ergan, "Integrating biometric sensors, vr, and machine learning to classify eeg signals in alternative architecture designs," in Computing in Civil Engineering 2019: Visualization, Information Modeling, and Simulation, pp. 169-176, American Society of Civil Engineers Reston, VA, 2019. 
[34] S. Ergan, A. Radwan, Z. Zou, H.-a. Tseng, and X. Han, "Quantifying human experience in architectural spaces with integrated virtual reality and body sensor networks," Journal of Computing in Civil Engineering, vol. 33, no. 2, p. 04018062, 2019.

[35] G. Vecchiato, A. Jelic, G. Tieri, A. G. Maglione, F. De Matteis, and F. Babiloni, "Neurophysiological correlates of embodiment and motivational factors during the perception of virtual architectural environments," Cognitive processing, vol. 16, no. 1, pp. 425-429, 2015.

[36] J. L. Higuera-Trujillo, C. Llinares Millán, A. Montañana i Aviñó, and J.-C. Rojas, "Multisensory stress reduction: a neuro-architecture study of paediatric waiting rooms," Building Research \& Information, vol. 48, no. 3, pp. 269285, 2020.

[37] P. Aspinall, P. Mavros, R. Coyne, and J. Roe, "The urban brain: analysing outdoor physical activity with mobile eeg," British journal of sports medicine, vol. 49, no. 4, pp. 272-276, 2015.

[38] C. Neale, P. Aspinall, J. Roe, S. Tilley, P. Mavros, S. Cinderby, R. Coyne, N. Thin, G. Bennett, and C. W. Thompson, "The aging urban brain: analyzing outdoor physical activity using the emotiv affectiv suite in older people," Journal of Urban Health, vol. 94, no. 6, pp. 869-880, 2017.

[39] A. Karandinou and L. Turner, "Architecture and neuroscience; what can the eeg recording of brain activity reveal about a walk through everyday spaces?," International Journal of Parallel, Emergent and Distributed Systems, vol. 32, no. sup1, pp. S54-S65, 2017.

[40] L. Al-Barrak, E. Kanjo, and E. M. Younis, "Neuroplace: Categorizing urban places according to mental states," PloS one, vol. 12, no. 9, p. e0183890, 2017.

[41] W. Zhang, X. He, S. Liu, T. Li, J. Li, X. Tang, and S. Lai, "Neural correlates of appreciating natural landscape and landscape garden: Evidence from an fmri study," Brain and Behavior, vol. 9, no. 7, p. e01335, 2019.

[42] S. Sakellaridi, P. Christova, V. Christopoulos, A. C. Leuthold, J. Peponis, and A. P. Georgopoulos, "Neural mechanisms underlying the exploration of small city maps using magnetoencephalography," Experimental brain research, vol. 233, no. 11, pp. 3187-3200, 2015.

[43] A. Olszewska-Guizzo, N. Escoffier, J. Chan, and T. Puay Yok, "Window view and the brain: Effects of floor level and green cover on the alpha and beta rhythms in a passive exposure eeg experiment," International journal of environmental research and public health, vol. 15, no. 11, p. 2358, 2018.

[44] P. Naghibi Rad, A. A. Shahroudi, H. Shabani, and R. Lashgari, "Encoding pleasant and unpleasant expression of the architectural window shapes: An erp study,"
Frontiers in behavioral neuroscience, vol. 13, p. 186, 2019.

[45] K. Chamilothori, G. Chinazzo, J. Rodrigues, E. DanGlauser, J. Wienold, and M. Andersen, "Subjective and physiological responses to façade and sunlight pattern geometry in virtual reality," Building and Environment, vol. 150, pp. 144-155, 2019.

[46] J. Bermudez, D. Krizaj, D. L. Lipschitz, C. E. Bueler, J. Rogowska, D. Yurgelun-Todd, and Y. Nakamura, "Externally-induced meditative states: an exploratory fmri study of architects' responses to contemplative architecture," Frontiers of architectural research, vol. 6, no. 2, pp. 123-136, 2017.

[47] A. M. Hakak, J. Bhattacharya, N. Biloria, R. de Kleijn, and F. Shah-Mohammadi, "Navigating abstract virtual environment: an eeg study," Cognitive neurodynamics, vol. 10, no. 6, pp. 471-480, 2016.

[48] Y. J. Son and C. Chun, "Research on electroencephalogram to measure thermal pleasure in thermal alliesthesia in temperature step-change environment," Indoor air, vol. 28, no. 6, pp. 916-923, 2018.

[49] X. Shan, E.-H. Yang, J. Zhou, and V. W. Chang, "Neuralsignal electroencephalogram (eeg) methods to improve human-building interaction under different indoor air quality," Energy and Buildings, vol. 197, pp. 188-195, 2019.

[50] E. Tiago-Costa, E. Quelhas-Costa, and J. Santos-Baptista, "Changes in eeg amplitude (alpha and beta waves) with thermal environment," Dyna, vol. 83, no. 197, pp. 87-93, 2016.

[51] D. Pati, M. O’Boyle, C. Amor, J. Hou, S. Valipoor, and D. Fang, "Neural correlates of nature stimuli: an fmri study," HERD: Health Environments Research \& Design Journal, vol. 7, no. 2, pp. 9-28, 2014.

[52] I.-C. Tang, Y.-P. Tsai, Y.-J. Lin, J.-H. Chen, C.-H. Hsieh, S.-H. Hung, W. C. Sullivan, H.-F. Tang, and C.-Y. Chang, "Using functional magnetic resonance imaging (fmri) to analyze brain region activity when viewing landscapes," Landscape and Urban Planning, vol. 162, pp. 137-144, 2017.

[53] J. Gottlieb, M. Cohanpour, Y. Li, N. Singletary, and E. Zabeh, "Curiosity, information demand and attentional priority," Current Opinion in Behavioral Sciences, vol. 35, pp. 83-91, 2020.

[54] M. L. Platt and S. A. Huettel, "Risky business: the neuroeconomics of decision making under uncertainty," $\mathrm{Na}$ ture neuroscience, vol. 11, no. 4, pp. 398-403, 2008.

[55] H. Eichenbaum, "The role of the hippocampus in navigation is memory," Journal of neurophysiology, vol. 117, no. 4, pp. 1785-1796, 2017. 
Figures

\begin{tabular}{|lc|}
\hline \multicolumn{2}{|c|}{ Databases } \\
\hline Springer & 6353 \\
Science direct & 1755 \\
Scopus & 12 \\
Pubmed & 16 \\
Web of science & 31 \\
\hline \multicolumn{2}{|c|}{ Total } \\
\hline \multicolumn{2}{|c|}{ Keywords } \\
\hline \multicolumn{2}{|c|}{} \\
\hline Architecture+Built environment+FMRI \\
Architecture+Built environment+EEG \\
Architecture+Built environment+Neuroscience \\
\hline
\end{tabular}

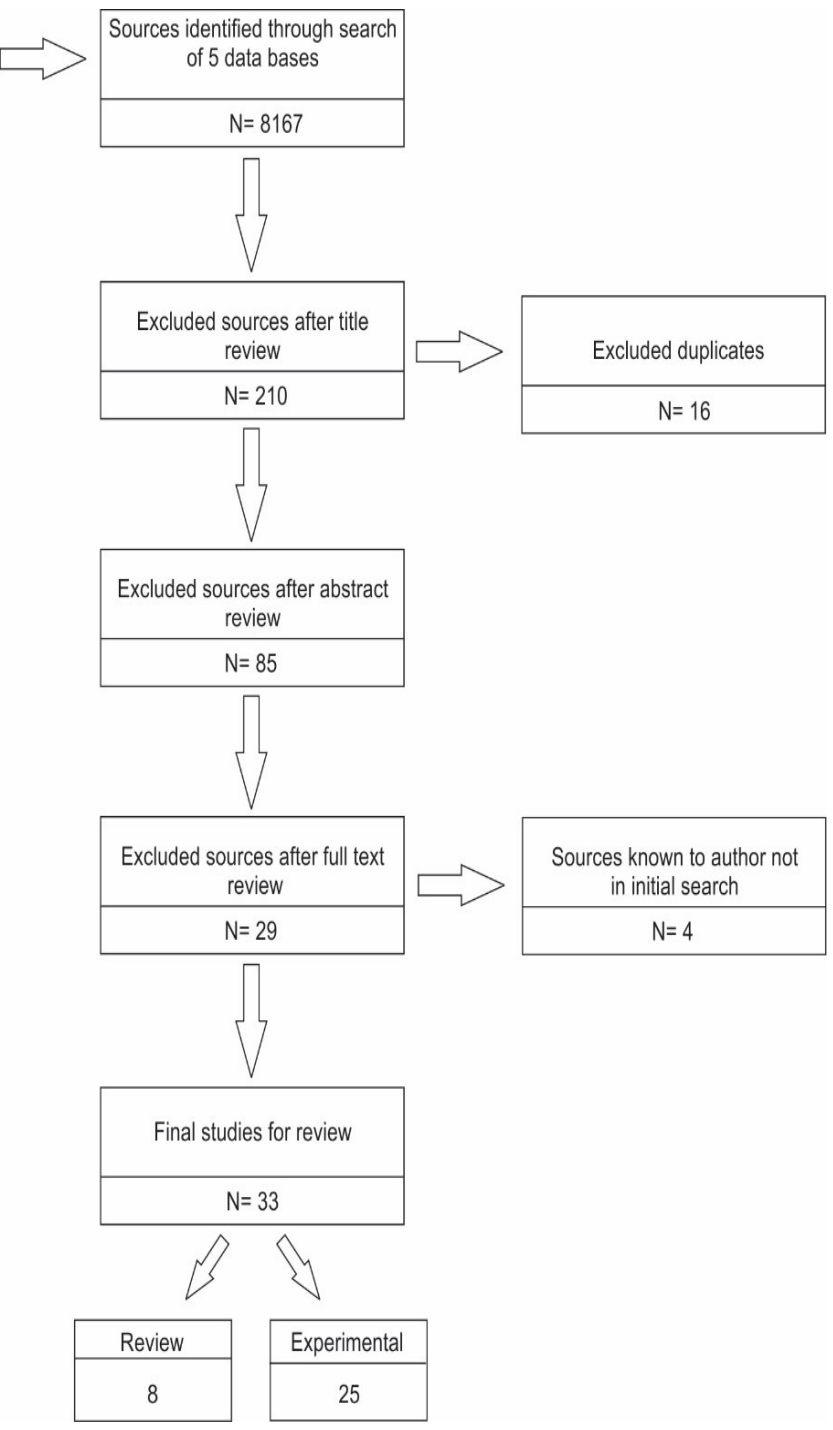

Fig. 1. Flow diagram of the article selection process 


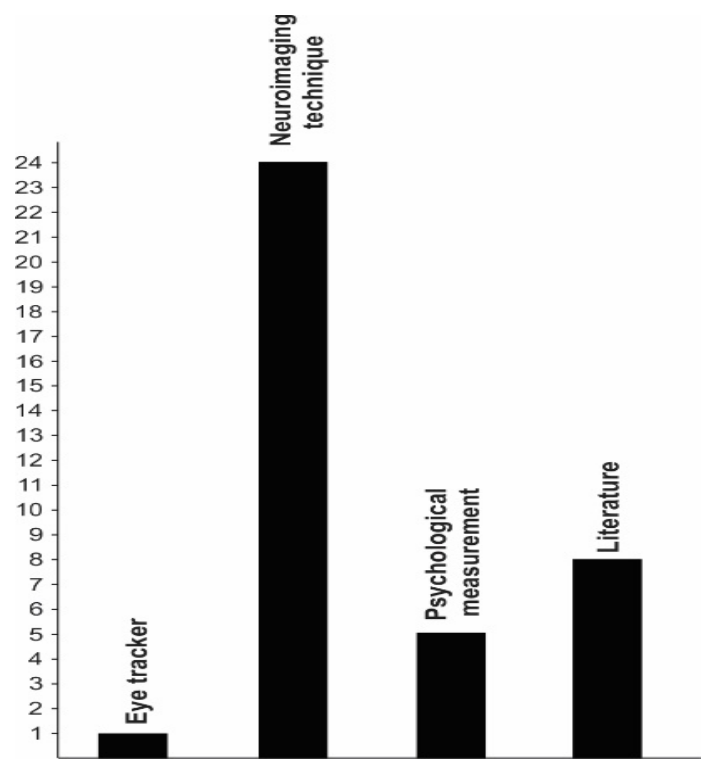

Fig. 2. The instruments were employed to measure brain activity

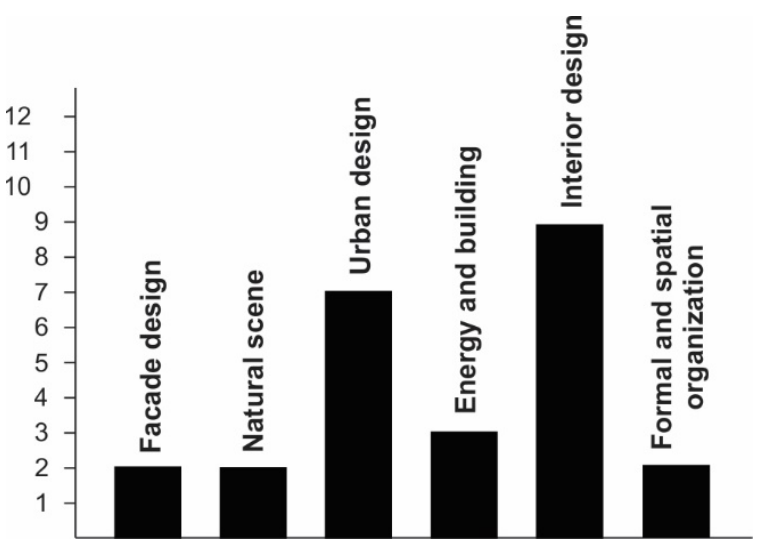

Fig. 3. The number of extracted main categories among final sources 


\section{Tables}

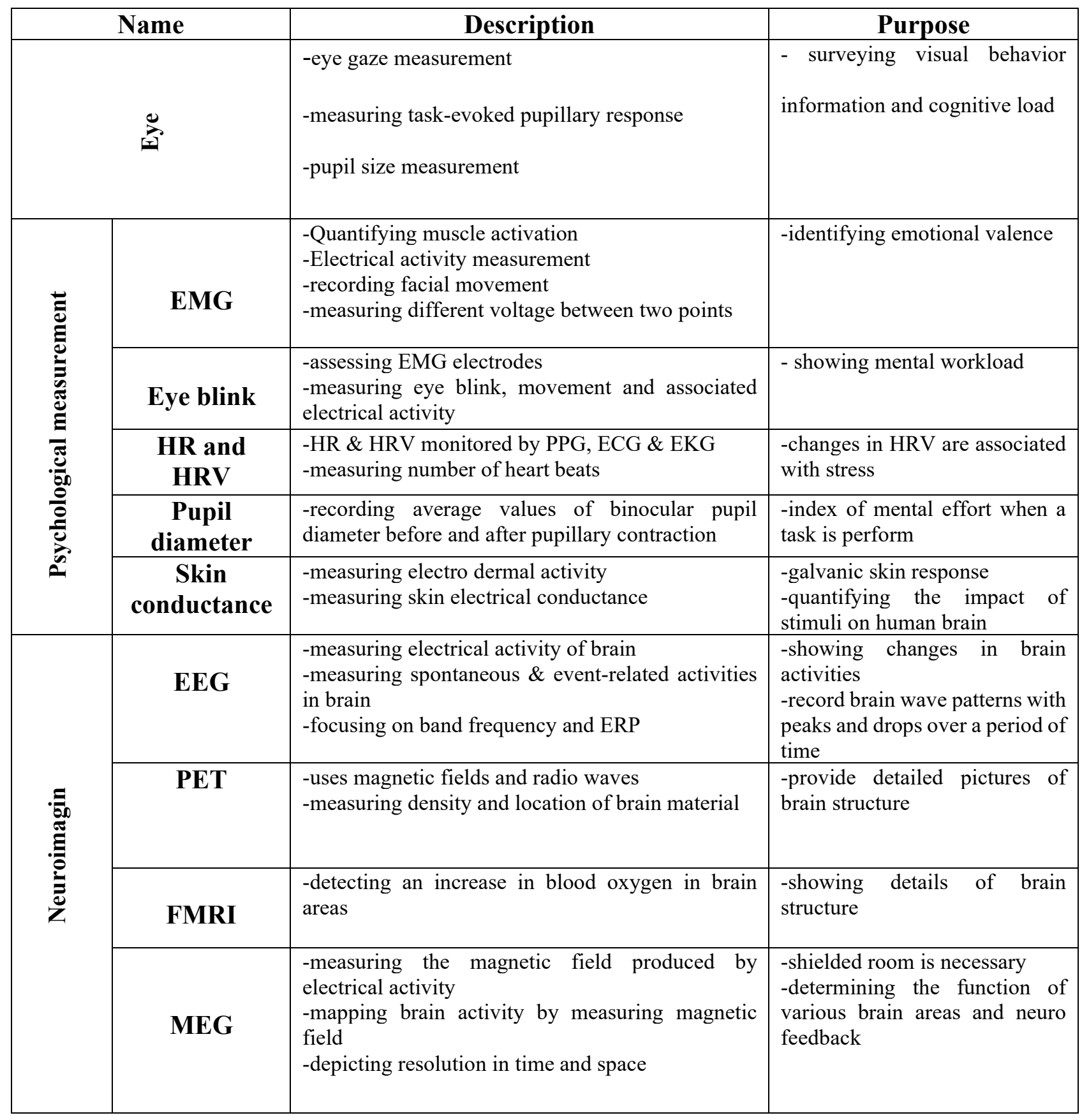

Table 1. A brief explanation of measurement tools 


\begin{tabular}{|c|c|c|c|}
\hline Database & Date & Search & Findings \\
\hline Science direct & 28.08 .2019 & Title & 1755 \\
\hline Springer & 02.09 .2019 & Title & 6353 \\
\hline Scopus & 29.08 .2019 & Title & 12 \\
\hline Web of science & 29.08 .2019 & Title & 31 \\
\hline PubMed & 26.08 .2019 & Title & 16 \\
\hline
\end{tabular}

Table 2. List of searched databases 


\begin{tabular}{|c|c|c|c|c|c|c|c|c|c|c|c|c|c|c|c|c|c|c|c|c|c|c|c|c|c|}
\hline Questions & $\mathrm{a}$ & $\mathrm{b}$ & $\mathrm{c}$ & $\mathrm{d}$ & $\mathrm{e}$ & $\mathrm{f}$ & $\mathrm{g}$ & $\mathrm{h}$ & $\mathrm{i}$ & $\mathrm{j}$ & $\mathrm{k}$ & 1 & $\mathrm{~m}$ & $\mathrm{n}$ & 0 & $\mathrm{p}$ & $q$ & $\mathrm{r}$ & $\mathrm{s}$ & $\mathrm{t}$ & $\mathrm{u}$ & $\mathrm{v}$ & $\mathrm{w}$ & $\mathrm{x}$ & $\mathrm{y}$ \\
\hline Purpose clearly stated & 1 & 1 & 1 & 1 & 1 & 1 & 1 & 1 & 1 & 1 & 1 & 1 & 1 & 1 & 1 & 1 & 1 & 1 & 1 & 1 & 1 & 1 & 1 & 1 & 1 \\
\hline $\begin{array}{l}\text { Relevant literature } \\
\text { reviewed }\end{array}$ & 1 & 1 & 1 & 1 & 0 & 1 & 1 & 1 & 1 & 0 & 1 & 1 & 1 & 1 & 1 & 1 & 1 & 1 & 1 & 1 & 1 & 1 & 0 & 1 & 1 \\
\hline Sample described in detail & 1 & 1 & 1 & 0 & 1 & 0 & 1 & 0 & 1 & 0 & 1 & 0 & 1 & 1 & 0 & 1 & 1 & 1 & 1 & 1 & 1 & 0 & 0 & 1 & 1 \\
\hline Sample size justified & 1 & 1 & 1 & 1 & 1 & 1 & 1 & 1 & 1 & 1 & 1 & 1 & 1 & 1 & 1 & 1 & 1 & 1 & 1 & 1 & 1 & 1 & 1 & 1 & 1 \\
\hline $\begin{array}{l}\text { Outcome measures } \\
\text { reliable }\end{array}$ & 1 & 1 & 1 & 1 & 1 & 1 & 1 & 1 & 1 & 0 & 1 & 1 & 1 & 1 & 1 & 1 & 1 & 1 & 1 & 1 & 1 & 1 & 1 & 1 & 1 \\
\hline Outcome measures valid & 1 & 1 & 1 & 1 & 1 & 1 & 1 & 1 & 1 & 1 & 1 & 1 & 1 & 1 & 1 & 1 & 1 & 1 & 1 & 1 & 1 & 1 & 1 & 1 & 1 \\
\hline $\begin{array}{l}\text { Intervention described in } \\
\text { detail }\end{array}$ & 1 & 1 & 1 & 1 & 1 & 1 & 1 & 1 & 1 & 1 & 1 & 1 & 1 & 1 & 1 & 1 & 1 & 1 & 1 & 1 & 1 & 1 & 1 & 1 & 1 \\
\hline Contamination avoided & 1 & 1 & 1 & 0 & 1 & 0 & 0 & 1 & 1 & 0 & 0 & 1 & 1 & 0 & 1 & 0 & 1 & 1 & 0 & 0 & 1 & 1 & 1 & 1 & 0 \\
\hline Co-intervention avoided & 1 & 1 & 1 & 1 & 1 & 1 & 1 & 1 & 1 & 1 & 1 & 1 & 1 & 1 & 1 & 1 & 1 & 1 & 1 & 1 & 1 & 1 & 1 & 1 & 1 \\
\hline $\begin{array}{l}\text { Reported significant } \\
\text { statistical result }\end{array}$ & 1 & 1 & 1 & 1 & 1 & 0 & 1 & 1 & 1 & 0 & 0 & 0 & 1 & 0 & 1 & 1 & 1 & 1 & 1 & 1 & 1 & 1 & 1 & 1 & 1 \\
\hline $\begin{array}{l}\text { Appropriate analysis } \\
\text { method }\end{array}$ & 1 & 1 & 1 & 1 & 1 & 1 & 1 & 1 & 1 & 1 & 1 & 1 & 1 & 1 & 1 & 1 & 1 & 1 & 1 & 1 & 1 & 1 & 1 & 1 & 1 \\
\hline Reported Drop-outs & 1 & 1 & - & 1 & 1 & - & 1 & - & - & - & 1 & - & 1 & - & - & - & 1 & 1 & 1 & 1 & - & - & - & 1 & 1 \\
\hline Appropriate Conclusions & 1 & 1 & 1 & 1 & 1 & 1 & 1 & 1 & 1 & 1 & 1 & 1 & 1 & 1 & 1 & 1 & 1 & 1 & 1 & 1 & 1 & 1 & 1 & 1 & 1 \\
\hline Total/13 & 13 & 13 & 12 & 11 & 12 & 9 & 12 & 11 & 12 & 7 & 11 & 10 & 12 & 10 & 11 & 11 & 13 & 13 & 12 & 12 & 12 & 11 & 10 & 13 & 12 \\
\hline
\end{tabular}

Table 3. Qualitative studies: McMaster Review Form

For each criterion: $1=$ criterion met; $0=$ criterion not met or unclear if met

a. Banaei et al. (2017); b. Shemesh et al. (2015); c. Pati et al. (2016); d. Vartanian et al. (2015); e. Hekmatmanesh et al. (2019); f. Zou et al. (2019); g. Ergan et al. (2018); h. Vecchiato et al. (2015); i. Higuera-Trujillo et al. (2019); j. Aspinall et al. (2013); k. Neale et al. (2017); 1. Karandinou et al. (2017); m. Al-barrak et al. (2017); n. Zhang et al. (2019); o. Sakellaridi et al. (2015); p. Olszewska-Guizzo et al. (2018); q. Naghibi Rad et al. (2019); r. Chamilothori et al. (2019); s. Bermudez. (2017); t. Mahdizadeh Hakak et al. (2016); u. Son et al. (2018); v. Shan et al. (2019); w. Tiago-Costa et al. (2016); x. Pati et al. (2014); y. Tang et al. (2017) 


\begin{tabular}{|c|c|c|c|c|c|c|c|}
\hline \multicolumn{2}{|r|}{ Title } & \multirow{2}{*}{$\begin{array}{c}\begin{array}{c}\text { Year and } \\
\text { country } \\
\text { of }\end{array} \\
\text { Publicati } \\
\text { on }\end{array}$} & \multirow{2}{*}{$\begin{array}{c}\text { Aim of study } \\
\\
\text { Investigating the } \\
\text { neurophysiological } \\
\text { correlates of different } \\
\text { interior forms on the } \\
\text { perceivers' affective } \\
\text { state and the } \\
\text { accompanying brain } \\
\text { activity }\end{array}$} & \multirow{2}{*}{$\begin{array}{c}\text { Data } \\
\text { Measure } \\
\\
\text { Emotive } \\
\text { EEG }\end{array}$} & \multirow{2}{*}{$\begin{array}{c}\text { Stimulus Features } \\
\\
\\
25 \text { different form clusters } \\
\text { were extracted from } 343 \\
\text { interior images of living } \\
\text { rooms from different } \\
\text { architectural epochs with } \\
\text { varying architectural } \\
\text { styles }\end{array}$} & \multirow{2}{*}{$\begin{array}{c}\begin{array}{c}\text { Stimuli } \\
\text { presentation }\end{array} \\
\\
\text { Virtual } \\
\text { Reality }\end{array}$} & \multirow{2}{*}{$\begin{array}{c}\text { Findings } \\
\\
\\
\text { A strong impact of } \\
\text { curvature geometries } \\
\text { on activity in the } \\
\text { anterior cingulate } \\
\text { cortex (ACC) }\end{array}$} \\
\hline 1 & $\begin{array}{l}\text { Walking through } \\
\text { Architectural Spaces: } \\
\text { The Impact of Interior } \\
\text { Forms on Human } \\
\text { Brain Dynamics }\end{array}$ & & & & & & \\
\hline 2 & $\begin{array}{c}\text { Space and human } \\
\text { perception - Exploring } \\
\text { our reaction to } \\
\text { different geometries of } \\
\text { spaces }\end{array}$ & $\begin{array}{l}2015 \\
\text { Israel }\end{array}$ & $\begin{array}{l}\text { Examining the } \\
\text { emotional response of } \\
\text { designers and non- } \\
\text { designers to various } \\
\text { spatial geometries in } \\
\text { an immersive 3D } \\
\text { virtual environment }\end{array}$ & $\begin{array}{l}\text { - Emotive } \\
\text { EEG } \\
\text { - Eye } \\
\text { tracking } \\
\text { - EEM }\end{array}$ & $\begin{array}{c}\text { Four types of spaces: } \\
\text { - Square symmetrical } \\
\text { space } \\
\text { - Round domed space or } \\
\text { half a sphere, symmetrical } \\
\text { - Sharp edged space, tilted } \\
\text { surfaces (walls, ceiling), } \\
\text { unsymmetrical } \\
\text { - Curvy space with } \\
\text { rounded smooth surfaces } \\
\text { (with no corners), } \\
\text { unsymmetrical }\end{array}$ & $\begin{array}{l}\text { Virtual } \\
\text { Reality }\end{array}$ & $\begin{array}{l}\text { non-experts are more } \\
\text { interested in curvy } \\
\text { spaces and felt more } \\
\text { pleasant feeling in } \\
\text { familiar spaces than the } \\
\text { experts }\end{array}$ \\
\hline 3 & $\begin{array}{l}\text { Can Hospital Form } \\
\text { Trigger Fear } \\
\text { Response? }\end{array}$ & $\begin{array}{l}2016 \\
\text { USA }\end{array}$ & $\begin{array}{c}\text { How exposure } \\
\text { to curve versus sharp } \\
\text { contours in healthcare } \\
\text { settings produce } \\
\text { systematic and } \\
\text { identifiable patterns } \\
\text { of amygdala activation } \\
\text { and behavioral } \\
\text { response in healthy } \\
\text { adults }\end{array}$ & fMRI & $\begin{array}{l}312 \text { real-life images } \\
\text { (objects, interiors, } \\
\text { exteriors, landscape, and a } \\
\text { set of control images) }\end{array}$ & $\begin{array}{l}\text { Display } \\
\text { images }\end{array}$ & $\begin{array}{c}\text { significant higher } \\
\text { Activation of amygdala } \\
\text { associated with curve } \\
\text { contours }\end{array}$ \\
\hline 4 & $\begin{array}{l}\text { Architectural design } \\
\text { and the brain: Effects } \\
\text { of ceiling height and } \\
\text { perceived enclosure on } \\
\text { beauty judgments and } \\
\text { approach-avoidance } \\
\text { decisions }\end{array}$ & $\begin{array}{c}2015 \\
\text { Canada, } \\
\text { USA, } \\
\text { Denmark, } \\
\text { Spain, } \\
\text { Australia }\end{array}$ & $\begin{array}{l}\text { Comparison the effects } \\
\text { of ceiling height } \\
\text { (low/high) and } \\
\text { perceived enclosure on } \\
\text { beauty judgment and } \\
\text { approach and } \\
\text { approach-avoidance } \\
\text { decisions in } \\
\text { architectural design }\end{array}$ & -FMRI & $\begin{array}{l}\text { Ceiling height and } \\
\text { perceived enclosure }\end{array}$ & $\begin{array}{l}\text { Display } \\
\text { images }\end{array}$ & $\begin{array}{l}\text { Higher ceilings were } \\
\text { judge as beautiful and } \\
\text { activated structures } \\
\text { involved in } \\
\text { visuospatial } \\
\text { exploration and } \\
\text { attention in dorsal } \\
\text { stream } \\
\text { - open room were } \\
\text { judge as beautiful and } \\
\text { activated structures } \\
\text { underlying perceived } \\
\text { visual motion } \\
\text { - enclose room elicit } \\
\text { exit decisions \& } \\
\text { activate the anterior } \\
\text { midcingulate cortex }\end{array}$ \\
\hline 5 & $\begin{array}{c}\text { Bedroom Design } \\
\text { Orientation and Sleep } \\
\text { Electroencephalograph } \\
\text { y Signals }\end{array}$ & $\begin{array}{l}2019 \\
\text { Iran, } \\
\text { Finland }\end{array}$ & $\begin{array}{l}\text { Assessing the effects } \\
\text { of bed orientation on } \\
\text { sleep quality to } \\
\text { enhance bedroom } \\
\text { design }\end{array}$ & -EEG & $\begin{array}{l}\text { Two rooms with identical } \\
\text { interior design and } \\
\text { different bed orientation } \\
\text { (north-south vs. east-west) }\end{array}$ & $\begin{array}{l}\text { Real } \\
\text { environment } \\
\text { (bedroom) }\end{array}$ & $\begin{array}{l}\text { - Significant changes in } \\
\text { delta, theta and alpha } \\
\text { frequencies in terms of } \\
\text { bed orientation } \\
\text { - Significant results in } \\
\text { alpha energy ratio } \\
\text { - Increases in the } \\
\text { average energy of } \\
\text { delta, theta, alpha } \\
\text { bands in N-S versus E- } \\
\text { W bed directions }\end{array}$ \\
\hline
\end{tabular}




\begin{tabular}{|c|c|c|c|c|c|c|c|}
\hline 6 & $\begin{array}{l}\text { Integrating Biometric } \\
\text { Sensors, VR, and } \\
\text { Machine Learning to } \\
\text { Classify EEG Signals } \\
\text { in Alternative } \\
\text { Architecture Designs }\end{array}$ & $\begin{array}{l}2019 \\
\text { USA }\end{array}$ & $\begin{array}{c}\text { Building a general } \\
\text { classification model to } \\
\text { label whether a design } \\
\text { has motivating effect } \\
\text { on human, regardless } \\
\text { of signatures on EEG } \\
\text { data imposed by } \\
\text { individuals }\end{array}$ & $\begin{array}{l}\text { Mobile EEG } \\
\text { headsets }\end{array}$ & $\begin{array}{l}\text { Four architectural design } \\
\text { features were used: } \\
\text { - presence of color } \\
\text { - texture of Surfaces } \\
\text { - proportional space layout } \\
\text { - well-connected and } \\
\text { logically sequenced spaces }\end{array}$ & $\begin{array}{l}\text { Virtual } \\
\text { Reality }\end{array}$ & $\begin{array}{l}\text { - ANN showed the } \\
\text { best performing } \\
\text { models in user } \\
\text { dependent/independent } \\
\text { analysis } \\
\text { - The accuracy of user } \\
\text { independent analysis } \\
\text { was lower than user } \\
\text { dependent one }\end{array}$ \\
\hline 7 & $\begin{array}{l}\text { Quantifying Human } \\
\text { Experience in } \\
\text { Architectural Spaces } \\
\text { with Integrated Virtual } \\
\text { Reality and Body } \\
\text { Sensor Networks }\end{array}$ & $\begin{array}{l}2018 \\
\text { USA }\end{array}$ & $\begin{array}{l}\text { Quantifying impact of } \\
\text { architectural design } \\
\text { features on stress and } \\
\text { anxiety }\end{array}$ & $\begin{array}{l}\text { - EEG } \\
\text { emotive } \\
\text { - GRS } \\
\text { (galvanic } \\
\text { skin } \\
\text { response) } \\
\text { - EMG } \\
\text { - PPG }\end{array}$ & $\begin{array}{l}\text { Two VE corresponding to } \\
\text { the two ends of the scale } \\
\text { for positively configured } \\
\text { (i.e., stress-reducing or } \\
\text { relaxing) and negatively } \\
\text { configured (i.e., stress- } \\
\text { inducing or stressful) } \\
\text { environments }\end{array}$ & $\begin{array}{l}\text { Virtual } \\
\text { Reality }\end{array}$ & $\begin{array}{l}\text { The human response } \\
\text { changes with } \\
\text { architectural design, } \\
\text { with more than } 40 \% \text { of } \\
\text { the } \\
\text { electroencephalogram } \\
\text { (EEG) oscillations } \\
\text { having higher values } \\
\text { across all channels on } \\
\text { all frequency bands, } \\
141 \% \text { having an } \\
\text { increase in galvanic } \\
\text { skin response (GSR) } \\
\text { readings, and lower } \\
\text { heart rate variability in } \\
\text { photoplethysmogram } \\
\text { (PPG) in the stress- } \\
\text { reducing environment }\end{array}$ \\
\hline 8 & $\begin{array}{c}\text { Neurophysiological } \\
\text { correlates of } \\
\text { embodiment and } \\
\text { motivational factors } \\
\text { during the perception } \\
\text { of virtual architectural } \\
\text { environments }\end{array}$ & $\begin{array}{l}2015 \\
\text { Italy }\end{array}$ & $\begin{array}{l}\text { Investigate the } \\
\text { neurophysiological } \\
\text { reactions related to the } \\
\text { appreciation of } \\
\text { ambiances }\end{array}$ & EEG & $\begin{array}{l}\text { Three rooms in real size }(5 \\
* 5 \mathrm{~m}) \text { with different } \\
\text { interior designs: } \\
\text { - cutting-edge furniture } \\
\text { - empty } \\
\text { - modern }\end{array}$ & $\begin{array}{l}\text { Display } \\
\text { images }\end{array}$ & $\begin{array}{c}\text { A correlation analysis } \\
\text { on personal judgments } \\
\text { returned that scores of } \\
\text { novelty, pleasantness } \\
\text { and comfort are } \\
\text { positively correlated, } \\
\text { while familiarity and } \\
\text { novelty are in negative } \\
\text { way }\end{array}$ \\
\hline 9 & $\begin{array}{l}\text { Multisensory stress } \\
\text { reduction: a } \\
\text { neuroarchitecture } \\
\text { study of paediatric } \\
\text { waiting rooms }\end{array}$ & $\begin{array}{c}2019 \\
\text { UK }\end{array}$ & $\begin{array}{l}\text { Analyzing the effect } \\
\text { that combinations of } \\
\text { different } \\
\text { environmental } \\
\text { satisfaction sources } \\
\text { have } \\
\text { on the stress reduction } \\
\text { of patients' } \\
\text { companions in a } \\
\text { paediatric service }\end{array}$ & $\begin{array}{c}- \text { EEG } \\
- \\
\text { psychologic } \\
\text { al responses }\end{array}$ & $\begin{array}{l}\text { - } 20 \text { waiting rooms were } \\
\text { assessed in order to select } \\
\text { the environmental sources } \\
\text { - Four simulated waiting } \\
\text { rooms combined selected } \\
\text { sources from the first } \\
\text { phase }\end{array}$ & $\begin{array}{l}\text { Virtual } \\
\text { Reality }\end{array}$ & $\begin{array}{l}\text { A combination of } \\
\text { environmental } \\
\text { satisfaction sources } \\
\text { creates an important } \\
\text { synergistic effect on } \\
\text { psychological and } \\
\text { neurophysiological } \\
\text { levels and underlines } \\
\text { the importance of } \\
\text { auditory and olfactory } \\
\text { stimuli }\end{array}$ \\
\hline 10 & $\begin{array}{l}\text { The urban brain: } \\
\text { Analyzing outdoor } \\
\text { physical activity with } \\
\text { mobile EEG }\end{array}$ & $\begin{array}{c}2013 \\
\text { UK }\end{array}$ & $\begin{array}{l}\text { - exploring ways of } \\
\text { using } \\
\text { electroencephalograph } \\
\text { y (EEG) technology in } \\
\text { the assessment of } \\
\text { urban experience } \\
\text { - analyzing the } \\
\text { emotional experience } \\
\text { of a group of walkers }\end{array}$ & $\begin{array}{l}\text { Emotive } \\
\text { EEG }\end{array}$ & $\begin{array}{l}\text { The route includes three } \\
\text { different areas: } \\
\text { - urban shopping street } \\
\text { - path through green } \\
\text { space, bordering lawns, } \\
\text { playing fields with trees } \\
\text { - busy commercial district } \\
\text { with heavy traffic }\end{array}$ & $\begin{array}{l}\text { Walking } \\
\text { through paths }\end{array}$ & $\begin{array}{l}\text { lower frustration, } \\
\text { engagement and } \\
\text { arousal, and higher } \\
\text { meditation was showed } \\
\text { when moving into the } \\
\text { green space zone; and } \\
\text { higher engagement } \\
\text { when moving out of it }\end{array}$ \\
\hline 11 & $\begin{array}{l}\text { The Aging Urban } \\
\text { Brain: Analyzing } \\
\text { Outdoor Physical } \\
\text { Activity Using the } \\
\text { Emotive Affective Suite } \\
\text { in Older People }\end{array}$ & $\begin{array}{c}2017 \\
\text { UK }\end{array}$ & $\begin{array}{l}\text { Understand the impact } \\
\text { of the urban } \\
\text { environment on neural } \\
\text { activity using } \\
\text { mobile EEG with older } \\
\text { participants }\end{array}$ & $\begin{array}{c}\text { Emotive } \\
\text { EEG }\end{array}$ & $\begin{array}{l}6 \text { walking scenarios from } \\
3 \text { different environments: } \\
\text { - urban busy } \\
\text { - urban green } \\
\text { - urban quiet }\end{array}$ & $\begin{array}{l}\text { Walking } \\
\text { through paths }\end{array}$ & $\begin{array}{l}\text { The results suggest that } \\
\text { there are neural } \\
\text { signatures associated } \\
\text { with the experience of } \\
\text { different urban spaces } \\
\text { which may reflect the } \\
\text { older age of the sample } \\
\text { as well as the condition } \\
\text { of the spaces } \\
\text { themselves }\end{array}$ \\
\hline
\end{tabular}




\begin{tabular}{|c|c|c|c|c|c|c|c|}
\hline 12 & $\begin{array}{l}\text { Architecture and } \\
\text { neuroscience; what can } \\
\text { the EEG recording of } \\
\text { brain activity reveal } \\
\text { about a walk-through } \\
\text { everyday space? }\end{array}$ & $\begin{array}{c}2018 \\
\text { UK }\end{array}$ & $\begin{array}{l}\text { The relation between } \\
\text { the variation of the } \\
\text { physical attributes of } \\
\text { the built environment } \\
\text { and fluctuation of brain } \\
\text { waves }\end{array}$ & $\begin{array}{l}\text { EEG } \\
\text { Emotive }\end{array}$ & $\begin{array}{l}\text { Physical features of built } \\
\text { environments }\end{array}$ & $\begin{array}{l}\text { Walking } \\
\text { through paths }\end{array}$ & $\begin{array}{l}\text { All the way finding- } \\
\text { decision moments } \\
\text { showed a short and } \\
\text { intense peak of beta } \\
\text { frequency }\end{array}$ \\
\hline 13 & $\begin{array}{c}\text { Neuro Place: } \\
\text { Categorizing urban } \\
\text { places according to } \\
\text { mental states }\end{array}$ & $\begin{array}{c}2017 \\
\text { UK }\end{array}$ & $\begin{array}{l}\text { - presenting a novel } \\
\text { urban place } \\
\text { recommendation } \\
\text { approach, that is based } \\
\text { on modelling in-situ } \\
\text { EEG data } \\
\text { - understanding the } \\
\text { restorative power of } \\
\text { outdoor environments } \\
\text { and guide people to } \\
\text { environments are } \\
\text { expected to calm them } \\
\text { down }\end{array}$ & $\begin{array}{l}\text { - wireless } \\
\text { EEG }\end{array}$ & $\begin{array}{c}\text { Three distinct places: } \\
\text { - Supermarket } \\
\text { - Garden } \\
\text { - Cafe }\end{array}$ & $\begin{array}{l}\text { Walking } \\
\text { through paths }\end{array}$ & $\begin{array}{l}\text { - High meditation } \\
\text { levels in garden and } \\
\text { cafe in comparison } \\
\text { with super market and } \\
\text { also, higher alpha } \\
\text { activity was noticed in } \\
\text { these places } \\
\text { - A higher beta activity } \\
\text { was observed in } \\
\text { supermarket which is } \\
\text { related to mental } \\
\text { activities }\end{array}$ \\
\hline 14 & $\begin{array}{l}\text { Neural correlates of } \\
\text { appreciating natural } \\
\text { landscape and } \\
\text { landscape garden: } \\
\text { Evidence from an } \\
\text { fMRI study }\end{array}$ & $\begin{array}{l}2019 \\
\text { China }\end{array}$ & $\begin{array}{l}\text { Identifying brain } \\
\text { regions associated with } \\
\text { perceptual \& cognitive } \\
\text { process when } \\
\text { presenting natural } \\
\text { landscape \& landscape } \\
\text { garden, cortical } \\
\text { differences in the } \\
\text { perception of } \\
\text { naturalness and } \\
\text { artificiality of } \\
\text { landscape }\end{array}$ & $\begin{array}{l}\text { - FMRI } \\
\text { - EPI }\end{array}$ & $\begin{array}{l}\text { Presenting the landscape } \\
\text { garden vs. natural } \\
\text { landscape in two versions } \\
\text { (original / lower definition } \\
\text { version) }\end{array}$ & $\begin{array}{l}\text { Display } \\
\text { images }\end{array}$ & $\begin{array}{l}\text { Strong activations in } \\
\text { inferior occipital lobe, } \\
\text { left superior parietal } \\
\text { lobule (SPL), right } \\
\text { fusiform gyrus, right } \\
\text { cuneus, and right } \\
\text { hippocampus that may } \\
\text { be specifically } \\
\text { associated with } \\
\text { appreciation of } \\
\text { landscape gardens }\end{array}$ \\
\hline 15 & $\begin{array}{c}\text { Neural mechanisms } \\
\text { underlying the } \\
\text { exploration of small } \\
\text { city maps using } \\
\text { magnetoencephalograp } \\
\text { hy }\end{array}$ & $\begin{array}{l}2015 \\
\text { USA }\end{array}$ & $\begin{array}{l}\text { assessing the } \\
\text { associations between } \\
\text { MEG time series and } \\
\text { map parameters }\end{array}$ & - MEG & $\begin{array}{l}4 \text { stimulants in } 5 \text { different } \\
\text { types of street networks } \\
(20 \text { stimulants in total) }\end{array}$ & $\begin{array}{l}\text { Display } \\
\text { images }\end{array}$ & $\begin{array}{l}\text { - A strong } \\
\text { concentration on right } \\
\text { frontal and prefrontal } \\
\text { areas during processing } \\
\text { street length and } \\
\text { regularity index } \\
\text { - Patches in prefrontal } \\
\text { areas were also } \\
\text { involved in processing } \\
\text { of the number of street } \\
\text { intersections }\end{array}$ \\
\hline 16 & $\begin{array}{c}\text { Window View and the } \\
\text { Brain: Effects of Floor } \\
\text { Level and Green Cover } \\
\text { on the Alpha and Beta } \\
\text { Rhythms in a Passive } \\
\text { Exposure EEG Experi } \\
\text { ment }\end{array}$ & $\begin{array}{c}2018 \\
\text { Singapore }\end{array}$ & $\begin{array}{l}\text { Investigated how the } \\
\text { combinations of } \\
\text { viewing height and the } \\
\text { amount of green can } \\
\text { impact the brainwaves } \\
\text { of viewers }\end{array}$ & $\begin{array}{l}\text { Emotive } \\
\text { EEG }\end{array}$ & $\begin{array}{l}\text { Thirty-six images } \\
\text { representing window } \\
\text { views from different floor } \\
\text { levels and with different } \\
\text { amounts of Greenery } \\
\text { (Editing Images with } 3 \\
\text { Different Green Levels) }\end{array}$ & $\begin{array}{l}\text { Display } \\
\text { images }\end{array}$ & $\begin{array}{l}\text { - The effects between } \\
\text { floor level, green } \\
\text { cover, brain waves, } \\
\text { - Considering the } \\
\text { quality of window } \\
\text { views \& their effects } \\
\text { on mental health and } \\
\text { well-being of urban } \\
\text { dwellers }\end{array}$ \\
\hline 17 & $\begin{array}{l}\text { Encoding pleasant and } \\
\text { unpleasant expression } \\
\text { of the architectural } \\
\text { window shapes: an } \\
\text { ERP study }\end{array}$ & $\begin{array}{c}2019 \\
\text { Iran }\end{array}$ & $\begin{array}{l}\text { Determining the } \\
\text { influence of building } \\
\text { façade with different } \\
\text { window shapes } \\
\text { (architectural features) } \\
\text { on brain activity and } \\
\text { emotional state }\end{array}$ & EEG & $\begin{array}{l}\text { Building façade with } \\
\text { different geometric } \\
\text { window shapes }\end{array}$ & $\begin{array}{l}\text { Display } \\
\text { images }\end{array}$ & $\begin{array}{l}\text { - More significant ERP } \\
\text { modulations in the } \\
\text { right than left } \\
\text { hemisphere for } \\
\text { unpleasant windows } \\
\text { compared to pleasant } \\
\text { ones } \\
\text { - Unpleasant stimuli } \\
\text { evoked larger ERP } \\
\text { amplitude than } \\
\text { pleasant } \\
\text { - Investigating changes } \\
\text { of ERP amplitude in } \\
\text { the frontal and central } \\
\text { (P2), parietal and } \\
\text { occipital (P3) lobes }\end{array}$ \\
\hline
\end{tabular}




\begin{tabular}{|c|c|c|c|c|c|c|c|}
\hline 18 & $\begin{array}{c}\text { Subjective and } \\
\text { physiological responses } \\
\text { to façade and sunlight } \\
\text { pattern geometry in } \\
\text { virtual reality }\end{array}$ & $\begin{array}{c}2019 \\
\text { Switzerlan } \\
\text { d }\end{array}$ & $\begin{array}{l}\text { providing substantial } \\
\text { evidence on how the } \\
\text { façade and the } \\
\text { resulting sunlight } \\
\text { pattern can jointly } \\
\text { affect the experience of } \\
\text { a space, taking into } \\
\text { consideration different } \\
\text { scenarios of use of } \\
\text { space }\end{array}$ & $\begin{array}{l}\text { - } \\
\text { physiologica } \\
1 \text { responses } \\
\text { (heart rate } \\
\text { and skin } \\
\text { conductance } \\
\text { ) }\end{array}$ & $\begin{array}{c}\text { Used a within subject } \\
\text { experimental design } \\
\text { included: } \\
\text { - subject factor façade } \\
\text { geometry with three levels } \\
\text { (Irregular, Regular, } \\
\text { Blinds) } \\
\text { - subject factor context } \\
\text { scenario with two levels } \\
\text { (social or working } \\
\text { context) }\end{array}$ & Virtual reality & $\begin{array}{l}\text { - Façade and sunlight } \\
\text { pattern geometry } \\
\text { affected heart rate } \\
\text { responses, but not skin } \\
\text { conductance responses } \\
\text { - participants showed a } \\
\text { larger decrease in heart } \\
\text { rate while exposed to } \\
\text { the Irregular condition } \\
\text { compared to the Blinds }\end{array}$ \\
\hline 19 & $\begin{array}{l}\text { Externally-induced } \\
\text { meditative states: an } \\
\text { exploratory fMRI study } \\
\text { of architects' responses } \\
\text { to contemplative } \\
\text { architecture }\end{array}$ & $\begin{array}{l}2017 \\
\text { USA }\end{array}$ & $\begin{array}{l}\text { Assessing the brain } \\
\text { activated patterns \& } \\
\text { subjective states \& } \\
\text { brain regions triggered } \\
\text { by contemplative vs } \\
\text { ordinary buildings }\end{array}$ & fMRI & $\begin{array}{l}\text { - Simulating an actual } \\
\text { walk from outside to } \\
\text { inside } \\
\text { - } 5 \text { popular buildings in } \\
\text { France, Rome, United } \\
\text { States, Spain, compared to } \\
\text { typical buildings such as } \\
\text { school, office and ... in } \\
\text { USA }\end{array}$ & $\begin{array}{l}\text { Display } \\
\text { images }\end{array}$ & $\begin{array}{c}\text { Results showed } \\
\text { significantly more } \\
\text { activation in both Left } \\
\text { Postcentral gyrus and } \\
\text { Left inferior parietal } \\
\text { lobule in the } \\
\text { experimental block in } \\
\text { comparison with } \\
\text { another block }\end{array}$ \\
\hline 20 & $\begin{array}{l}\text { Navigating abstract } \\
\text { virtual environment: } \\
\text { an EEG study }\end{array}$ & $\begin{array}{l}2016 \\
\text { The } \\
\text { Netherland } \\
\text { s \& UK }\end{array}$ & $\begin{array}{l}\text { Investigating the } \\
\text { difference between an } \\
\text { abstract designed } \\
\text { environment in } \\
\text { compare with a fully or } \\
\text { semi-designed } \\
\text { environment that has } \\
\text { some correlation with } \\
\text { the physical world }\end{array}$ & EEG & $\begin{array}{l}15 \text { movies in three } \\
\text { different categories of } \\
\text { designed environment: } \\
\text { - Abstract environment } \\
\text { - Semi-designed } \\
\text { environment } \\
\text { - Fully designed } \\
\text { environment }\end{array}$ & Display movie & $\begin{array}{l}\text { - Showed a decrease in } \\
\text { beta } 2 \text { activity for the } \\
\text { fully designed in } \\
\text { comparison with the } \\
\text { abstract designed } \\
\text { environments and a } \\
\text { small activation in beta } \\
3 \text { environments } \\
\text { - A comparison } \\
\text { between abstract } \\
\text { designed and semi- } \\
\text { designed environments } \\
\text { depicted a big } \\
\text { difference in both beta } \\
\text { band frequencies in the } \\
\text { precentral gyrus }\end{array}$ \\
\hline 21 & $\begin{array}{l}\text { Research on } \\
\text { electroencephalogram } \\
\text { to measure thermal } \\
\text { pleasure in thermal } \\
\text { Alliesthesia in } \\
\text { temperature step- } \\
\text { change environment }\end{array}$ & $\begin{array}{c}2018 \\
\text { Korea }\end{array}$ & $\begin{array}{c}\text { Investigating an } \\
\text { immediate impact of } \\
\text { thermal pleasure on } \\
\text { EEG under } \\
\text { temperature step- } \\
\text { change environment to } \\
\text { discover rapid } \\
\text { psychological change } \\
\text { from physiological } \\
\text { data }\end{array}$ & - EEG & $\begin{array}{l}\text { The experimental } \\
\text { conditions, including } \\
\text { spatial dimensions, of the } \\
\text { two rooms needed to be } \\
\text { the same, except for air } \\
\text { temperature, radiant } \\
\text { temperature and relative } \\
\text { humidity-the } \\
\text { independent variables }\end{array}$ & $\begin{array}{l}\text { Being in a } \\
\text { climate } \\
\text { chamber } \\
\text { consisted of } \\
\text { two rooms }\end{array}$ & $\begin{array}{l}\text { EEG frequency band } \\
\text { associated with } \\
\text { pleasant emotional } \\
\text { (theta) increased while } \\
\text { frequency band related } \\
\text { to pleasantness, } \\
\text { satisfaction or } \\
\text { relaxation (beta) } \\
\text { decreased with thermal } \\
\text { pleasure }\end{array}$ \\
\hline 22 & $\begin{array}{c}\text { Neural-signal } \\
\text { electroencephalogram } \\
\text { (EEG) methods to } \\
\text { improve human- } \\
\text { building interaction } \\
\text { under different indoor } \\
\text { air quality }\end{array}$ & $\begin{array}{c}2019 \\
\text { Singapore } \\
\& \\
\text { Australia }\end{array}$ & $\begin{array}{l}\text { Investigate neural- } \\
\text { signal } \\
\text { electroencephalogram } \\
\text { (EEG) methods to } \\
\text { improve human- } \\
\text { building interaction } \\
\text { under different indoor } \\
\text { air quality conditions }\end{array}$ & - EEG & - & - & $\begin{array}{l}\text { Theta and alpha bands } \\
\text { have good potential to } \\
\text { improve the human- } \\
\text { building interaction as } \\
\text { more objective indices } \\
\text { and the machine } \\
\text { learning-based EEG } \\
\text { pattern recognition } \\
\text { methods as real-time } \\
\text { feedback mechanisms }\end{array}$ \\
\hline 23 & $\begin{array}{c}\text { Changes in EEG } \\
\text { amplitude (Alpha and } \\
\text { Beta } \\
\text { waves) with Thermal } \\
\text { environment }\end{array}$ & $\begin{array}{c}2016 \\
\text { Portugal }\end{array}$ & $\begin{array}{l}\text { Evaluate the influence } \\
\text { of temperature and } \\
\text { humidity directly on } \\
\text { brain activity while } \\
\text { performing a task }\end{array}$ & $\begin{array}{l}\text { - EEG } \\
\text { - Skin } \\
\text { thermal } \\
\text { sensors } \\
\text {-Internal } \\
\text { thermal } \\
\text { sensors }\end{array}$ & $\begin{array}{l}\text { A set of laboratory tests } \\
\text { were undertaken in two } \\
\text { different thermal } \\
\text { environments }\end{array}$ & $\begin{array}{l}\text { Being in a } \\
\text { climate } \\
\text { chamber } \\
\text { consisted of } \\
\text { two rooms }\end{array}$ & $\begin{array}{l}\text { - Alpha activity } \\
\text { analyses in hot thermal } \\
\text { environments showed a } \\
\text { decrease for both areas } \\
\text { of the occipital lobe } \\
\text { - In cold thermal } \\
\text { environment decrease } \\
\text { for half the time of the } \\
\text { test and then rises, } \\
\text { showing an increase } \\
\text { for both areas of the } \\
\text { occipital lobe }\end{array}$ \\
\hline
\end{tabular}




\begin{tabular}{|c|c|c|c|c|c|c|c|}
\hline 24 & $\begin{array}{l}\text { Neural Correlates of } \\
\text { Nature Stimuli: } \\
\text { An fMRI Study }\end{array}$ & $\begin{array}{l}2014 \\
\text { USA }\end{array}$ & $\begin{array}{l}\text { Explored a within- } \\
\text { subject experimental } \\
\text { design by exemplars of } \\
\text { the photographic sky } \\
\text { compositions on brain } \\
\text { activation patterns in } \\
\text { healthy adults }\end{array}$ & fMRI & $\begin{array}{c}\text { Three types of images } \\
\text { - positive } \\
\text { - negative, and } \\
\text { - neutral }\end{array}$ & $\begin{array}{l}\text { Display } \\
\text { images }\end{array}$ & $\begin{array}{l}\text { Activation patterns } \\
\text { produced by sky } \\
\text { compositions and } \\
\text { positive images were } \\
\text { quite similar and also } \\
\text { the patterns of negative } \\
\text { and neutral images are } \\
\text { similar }\end{array}$ \\
\hline 25 & $\begin{array}{l}\text { Using functional } \\
\text { Magnetic Resonance } \\
\text { Imaging (fMRI) to } \\
\text { analyze brain } \\
\text { region activity when } \\
\text { viewing landscapes }\end{array}$ & $\begin{array}{c}2017 \\
\text { Taiwan \& } \\
\text { USA }\end{array}$ & $\begin{array}{l}\text { demonstrated effect of } \\
\text { presenting different } \\
\text { landscapes on brain } \\
\text { regions activity }\end{array}$ & fMRI & $\begin{array}{c}\text { Four types of landscapes } \\
\text { - urban } \\
\text { - mountain } \\
\text { - forest } \\
\text { - water }\end{array}$ & $\begin{array}{l}\text { Display } \\
\text { images }\end{array}$ & $\begin{array}{l}\text { - Results indicated an } \\
\text { increased activity in } \\
\text { visual and attentional } \\
\text { concentration brain } \\
\text { areas when an urban } \\
\text { environment was } \\
\text { presented in } \\
\text { comparison with a } \\
\text { neutral stimulus } \\
\text { - Water and mountains } \\
\text { had the best attention- } \\
\text { restorative abilities } \\
\text { among the four types } \\
\text { of landscapes, followed } \\
\text { by the forest and urban } \\
\text { landscapes. }\end{array}$ \\
\hline
\end{tabular}

Table 4. Characteristics of all final studies for review 